\title{
THE ASSESSMENT OF SEDIMENT CONTAMINATION LEVEL IN THE LAMPUNG BAY, INDONESIA: HEAVY METAL PERSPECTIVE
}

\author{
Fitri Budiyanto1) \& Lestari1) \\ 1)Research Center for Oceanography, Indonesian Institute of Sciences \\ Diterima tanggal: 23 Februari 2015; Diterima setelah perbaikan: 5 Mei 2015; Disetujui terbit tanggal 1 Juli 2015
}

\begin{abstract}
ABSTRAK
Teluk Lampung memiliki nilai sosial-ekonomi dan ekologi yang tinggi berkaitan dengan potensi perairan dan penggunaannya oleh manusia. Di lain pihak, pemanfaatan Teluk Lampung mungkin mengubah kelimpahan bahan kimia berbahaya seperti logam berat. Tujuan dari penilitian ini untuk mengetahui konsentrasi logam berat $\mathrm{Cd}, \mathrm{Cu}, \mathrm{Pb}$ dan $\mathrm{Zn}$ dalam sedimen dan menilai kondisi periaran Teluk Lampung. Pengamatan konsentrasi logam berat dilakukan di 13 titik stasiun pada bulan maret 2008. Analisis logam berat dalam sedimen menggunakan tiga jenis asam: $\mathrm{HNO}_{3}, \mathrm{HCl}, \mathrm{H}_{2} \mathrm{O}_{2}$ kemudian sampel dianalisis menggunakan Spektrofotometer Serapan Atom. Hasil pengukuran menunjukkan variasi logam berat di setiap lokasi pengamatan dan konsentrasi tertinggi $\mathrm{Cd}, \mathrm{Cu}, \mathrm{Pb}$ dan $\mathrm{Zn}$ dalam sedimen secara berurutan adalah $0.08 \mathrm{mg} / \mathrm{kg}$ berat kering, $22.99 \mathrm{mg} / \mathrm{kg}$ berat kering, $24.75 \mathrm{mg} / \mathrm{kg}$ berat kering dan $118.48 \mathrm{mg} / \mathrm{kg}$ berat kering. Faktor yang dominan mempengaruhi variasi logam berat dalam sedimen dalam studi ini adalah jarak lokasi pengamatan dengan pusat kegiatan antropogenik dan fraksi sedimen. Indeks SQG-Q menunjukkan 7 titik stasiun memiliki nilai SQG-Q $\leq 0.1$ sementara 6 titik stasiun lainnya memiliki nilai $0.1 \leq S Q G-Q<1$. Hal ini berarti lebih dari setengah titik stasiun berada pada kondisi tidak tercemar.
\end{abstract}

\section{Kata kunci: Teluk Lampung, konsentrasi logam berat, indeks SQG-Q}

\section{ABSTRACT}

The potency and utilization of Lampung Bay has been recognized for their socio-economical and ecological values. However, heavy use of this Bay may alter the abundance of hazardous chemical like heavy metals. The aims of this study were to determine the concentration of $\mathrm{Cd}, \mathrm{Cu}, \mathrm{Pb}$ and $\mathrm{Zn}$ in the sediment and to assess Lampung Bay water condition. The observation of heavy metal content in sediment of Lampung Bay was conducted at 13 stations in March 2008. Analysis of heavy metals in sediment was conducted using three kinds of acid: $\mathrm{HNO}_{3}, \mathrm{HCl}$ and $\mathrm{H}_{2} \mathrm{O}_{2}$ while measurement was carried out by Atomic Absorption Spectrophotometer. The result indicated a variation of heavy metal concentration in sediment and that concentrations of $\mathrm{Cd}, \mathrm{Cu}, \mathrm{Pb}$ and $\mathrm{Zn}$ in sediment were $0.08 \mathrm{mg} / \mathrm{kg}$ dry weight, $22.99 \mathrm{mg} / \mathrm{kg}$ dry weight, $24.75 \mathrm{mg} / \mathrm{kg}$ dry weight and $118.48 \mathrm{mg} / \mathrm{kg}$ dry weight, respectively. Factors influenced heavy metal concentration in sediment in this study including the distance between sampling location and anthropogenic activities and the sediment fraction SQG-Q index indicated that 7 stations have $S Q G-Q \leq 0.1$ whereas other 6 stations have $0.1 \leq S Q G-Q<1$, meaning that more than half sampling stations are in uncontaminated state.

Keywords: Lampung Bay, heavy metals concentration, SQG-Q index

\section{INTRODUCTION}

Heavy metals enrich water body by several mechanisms (Lee \& Morel, 1985) and their abundance in sediment can represent level of contamination of the environment (Lestari \& Witasari, 2010). Riverine runoff becomes major source of metals in estuarine waters (Darmono, 1995) and depositional processes alter composition of metal in the sediment (Rompas, 2010). Changes of physicochemical properties $(\mathrm{pH}$, salinity, temperature, eH) provoke the release of metals in sediment into upper water column (Hosono et. al., 2010). Some of the released metals were redeposited in the sediment and this process will be repeated several times inflicting permanent release of metals into water column and/or permanent sink of metals into seabed sediment (Rejomon et. al., 2010).

Lampung bay is located in the southernmost part of Sumatra that shows socio-economical and ecological value due to its marine resources and utilization (Fitriya, 2010; Thoha, 2010). Mangrove, coral reef, seagrass, sand and mud are part of ecosystem diversity in Lampung Bay (Cappenberg, 2010; Handayani, 2010). Coastal communities utilize those resources for aquaculture activities, such as: pearl farming, seaweed aquaculture and tourism (Kadi, 2010; Pramudji, 2010).

Local Government of Lampung (1999) explained that Lampung receives spill-over of economic growth of Jakarta causing rapid enhancement of anthropogenic activities like industry, urban area, agriculture and aquaculture. According to Susana et. al., (2001), Lampung bay has been influenced by industrial activities like cement, coal, timber and oil production. These activities may alter metals concentration in aquatic ecosystem especially $\mathrm{Cd}, \mathrm{Cu}, \mathrm{Pb}$ and $\mathrm{Zn}$ which will be used and will be released in their production process (Darmono, 1995). The aims of this research were to determine $\mathrm{Cd}, \mathrm{Cu}, \mathrm{Pb}$ and $\mathrm{Zn}$ concentration in sediment and to assess its contamination level. 


\section{METHODOLOGY}

\section{Sampling site}

Sediment samples were collected in 13 observation stations in March 2008 in the geographical area of $105.22^{\circ}$ to $105.37^{\circ}$ East and $5.66^{\circ}$ to $5.46^{\circ}$ South (Figure 1). The stations were chosen representing local anthropogenic activities. Northern part of the Bay represents urban areas, and the western part is proximal to aquaculture area. The eastern part of the bay was selected for observation in the water near industrial area.

\section{The collection of sediment samples}

In each station, sample was taken using stainless steel grab sampler then $0-10 \mathrm{~cm}$ of surface-layer sediment was collected using Polyethylene spoon. In the field, sediment sample was stored in ice box at \pm $4^{\circ} \mathrm{C}$ in temperature (Hutagalung et. al., 1997).

\section{Analytical method}

Acidic destruction and spectrophotometry measurement were used to analyze sediment samples according to USEPA 3050b procedure (USEPA, 1996). HNO3 (1+1) was added into a gram of dry sediment then the solution was heated for 15 minutes. After the heating, concentrated $\mathrm{HNO}_{3}, \mathrm{H}_{2} \mathrm{O}_{2} \quad 30 \%$ and concentrated $\mathrm{HCl}$ were added by dropper into solution and reheating of solution was performed. Aquadest was added into sample solution to $100 \mathrm{ml}$ in volume. After the destruction processes finished, $\mathrm{Cd}, \mathrm{Cu}, \mathrm{Pb}$ and $\mathrm{Zn}$ in sediment were measured using Flame Atomic Absorption Spectrophotometer (FAAS) Varian SpectrAA 20 plus utilizing air-acetylene as ignition gas. Before used, all glasswares were soaked into $\mathrm{HNO} 3$ $(1+1)$ for 24 hours and were rinsed by aquadest.

To understand $\mathrm{Cd}, \mathrm{Cu}, \mathrm{Pb}$ and $\mathrm{Zn}$ concentration in sediment, sediment fraction was measured then PCA analysis was conducted to discover the influence of sediment fraction to the metals concentration. Statistica version 6.0 was used to perform PCAAnalysis and the sedimentary fraction data was taken from Helfinalis (2010) as a secondary data.

\section{Index Calculation}

Ecosystem changes by anthropogenic activities in this research were evaluated using SQG-Q (mean sediment quality guideline quotient) index. SQG-Q was used to determine pollution level in the bed sediment by comparing with quality guideline. Caeiro et. al., (2005) formulated SQG-Q index as:

$$
\begin{gathered}
S Q G-Q=\frac{\sum_{i=1}^{n} P E L-Q_{i}}{n} \\
P E L-Q i=\frac{\text { contaminant }}{P E L}
\end{gathered}
$$

PEL-Qi : probable effect level quotient for each contaminant

PEL : probable effect level for each contaminant (Tabel 1)

Contaminant : metals concentration in sediment $\mathrm{n} \quad$ : number of parameter for calculation

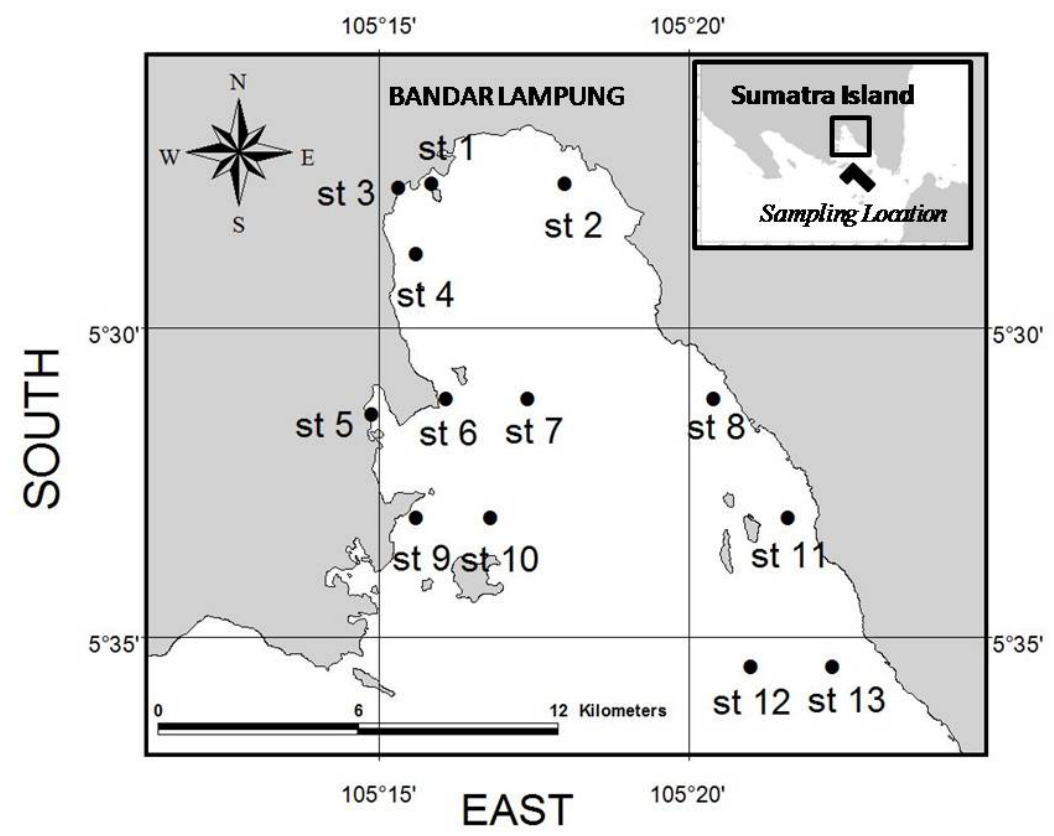

Figure 1. Sampling stations for sediment sample in the Lampung Bay. 
Table 1. The references for SQG-Q index

\begin{tabular}{lllll}
\hline Element & $\mathrm{Cd}$ & $\mathrm{Cu}$ & $\mathrm{Pb}$ & $\mathrm{Zn}$ \\
\hline Probable effect level (PEL) value for each metal, $\mathrm{mg} / \mathrm{kg}$ dry weight & 4,2 & 108 & 112 & 271 \\
\hline
\end{tabular}

Source:Nobi et. al., 2010

Table 2.

Interpretation of SQG-Q value

\begin{tabular}{ll}
\hline SQG-Q value & Designation of sediment quality \\
\hline SQG-Q $\leq 0,1$ & Unimpacted: lowest potential for observing adverse biological effects \\
$0,1<S Q G-Q \leq 1$ & Moderate impact potential for observing adverse biological effects \\
SQG-Q $\geq 1$ & Highly impacted potential for observing adverse biological effects \\
\hline
\end{tabular}

In this calculation, PEL values were used to figure out the index value (Table 1). The others value could be used to substitute PEL like quality standard of metals in the sediment, even though, substituting this value possibly changes the calculated index.

The value obtained from those calculations varied from 0 up to 1. Caeiro et. al., (2005) explained the meaning of the value of SQG-Q and the brief of that interpretation was summarized in Table 2.

\section{RESULT AND DISCUSSION}

Metals concentration varied among locations, and both anthropogenic activities and natural processes alter metals abundance. Cd became the lowest value and the tightest range of metals found in the bed sediment compared with $\mathrm{Cu}, \mathrm{Pb}$ and $\mathrm{Zn}$. On the opposite, $\mathrm{Zn}$ had the widest range of value among the others (Table 3 ). Cd shows the worst toxic effect and its presence in sediment probably affects benthic organism even in low concentration (Ellwood, 2004). Cd, Cu and Pb naturally exist in oil and coal then the utilizing of both oil and coal as fuel may release the metals into aquatic ecosystems. $\mathrm{Zn}$ has been categorized as essential metal which is required and is used in metabolism, however, recent researches showed that excessive uptake of $\mathrm{Zn}$ into organism body gives toxic effect (Dean et. al., 2007). Report of Zn hazards decribed that Zn deficiency have severe effects on all stages of growth, development, reproduction and survival, however, exceeding level of zinc causes negative effect.

Urban and aquaculture activities along Lampung Bay coast line influenced metals abundance. The high concentration of $\mathrm{Cu}, \mathrm{Pb}$ and $\mathrm{Zn}$ were detected in the river mouth and urban area, and those metals tend to decrease by the distance. Cd evenly distributed in this Lampung Bay, for Cd naturally presents in a little amount in earth crust (Taylor, 1964), so little changes in enviroment have no significant effect to $\mathrm{Cd}$ concentration. Sanusi (2006) explained that river flow includes human waste such as metals contaminant. Other researchers reported that increasing metals content in the river mouth was affected by input volume/runoff of river containing metals (Rochyatun et.

Table 3. Concentration of $\mathrm{Cd}, \mathrm{Cu}, \mathrm{Pb}$ and $\mathrm{Zn}$ in Sediment

\begin{tabular}{lllll} 
Station & \multicolumn{4}{c}{ Metal in sediment concentration } \\
& Cd & Cu & Pb & Zn \\
& & & & \\
& & & & \\
& & & \\
& & & \\
st 1 & 0.05 & 20.58 & 21.61 & 111.00 \\
st 2 & 0.05 & 22.99 & 24.73 & 118.48 \\
st 3 & 0.08 & 18.27 & 6.05 & 99.06 \\
st 4 & 0.03 & 5.30 & 7.28 & 35.27 \\
st 5 & 0.04 & 16.88 & 12.20 & 71.65 \\
st 6 & 0.04 & 12.84 & 11.94 & 61.67 \\
st 7 & 0.01 & 11.01 & 10.01 & 63.79 \\
st 8 & 0.02 & 8.39 & 9.23 & 33.14 \\
st 9 & 0.03 & 8.82 & 9.22 & 57.52 \\
st 10 & 0.03 & 9.06 & 9.29 & 63.11 \\
st 11 & 0.04 & 8.33 & 9.49 & 58.62 \\
st 12 & 0.02 & 7.12 & 9.88 & 52.99 \\
st 13 & 0.02 & 8.35 & 9.99 & 54.01 \\
\hline
\end{tabular}


al., 2005; Ciutat et. al., 2007). Rochyatun et. al., (2006) observed the impact of riverine runoff in the Cisadane river as long as the fluctuation of metals content on bed sediment by flooding phenomenon. Their research discovered that $\mathrm{Cd}$ and $\mathrm{Zn}$ increased in two fold of concentration after the flooding, however, $\mathrm{Pb}$ and $\mathrm{Cu}$ showed no differences between pra and post of the flooding. Urban activities contribute in metals input mostly by fuel combustion, paint weathering, metal furniture corrosion and urban waste disposal (Ciutat et. al., 2007). Aquaculture area contributes in $\mathrm{Cu}$ and $\mathrm{Zn}$ input into aquatic ecosystem. Dean et. al., (2007) reported the highest $\mathrm{Cu}$ and $\mathrm{Zn}$ concentration found in fish farming area which feed and faecal of fish contain of $\mathrm{Cu}$ and $\mathrm{Zn}$. In addition, $\mathrm{Cu}$ is used as antifouling in boat paint (Olsgard, 1999).

Sediment fraction also affected $\mathrm{Cd}, \mathrm{Cu}, \mathrm{Pb}$ and $\mathrm{Zn}$ concentration in bed sediment where clay fraction strongly bound $\mathrm{Cd}, \mathrm{Cu}, \mathrm{Pb}$ and $\mathrm{Zn}$ (Figure 2). Clay and silt concentrated in the urban and aquaculture area (Table 5) where $\mathrm{Cd}, \mathrm{Cu}, \mathrm{Pb}$ and $\mathrm{Zn}$ found in relatively high concentration. Considering the industrial area in the eastern part of the Bay have coarser sediment than the urban area metals concentration is in low concentration. Finer particles provide larger surface area, and these kinds of particle bind more metals onto particle. Moreover, finer particles form dense bed sediment inhibiting the realease of trapped-metals into water column (Donazzolo et. al., 1984; Martinctic et. al., 1990). River mouth and urban area of Lampung Bay tend to contain more clay and resulted in high concentration of metals detected in those areas (Figure 2).

Metals concentration in bed sediment of Lampung Bay is considered as natural concentration of metals in sediment. $\mathrm{Cd}, \mathrm{Cu}, \mathrm{Pb}$ and $\mathrm{Zn}$ concentration in sediment

Table 4.

Concentration of $\mathrm{Cd}, \mathrm{Cu}, \mathrm{Pb}$ and $\mathrm{Zn}$ in sediment in the other locations

\begin{tabular}{|c|c|c|c|c|c|}
\hline \multirow[t]{2}{*}{ Location } & \multicolumn{4}{|c|}{ Metals concentration in sediment, $\mathrm{mg} / \mathrm{kg}$ dry weight } & \multirow[t]{2}{*}{ Reference } \\
\hline & Cd & $\mathrm{Cu}$ & $\mathrm{Pb}$ & $\mathrm{Zn}$ & \\
\hline East Kalimantan, Indonesia & $<0.001-0.1$ & $2.02-14.5$ & $4.4-15.2$ & $15.8-121.2$ & Rochyatun, et. al., 2003 \\
\hline Pari Islands, Indonesia & $0.03-0.06$ & $13.24-15.93$ & 0.84-6.01 & $0.73-17.83$ & Rochyatun, 2003 \\
\hline Semarang, Indonesia & $0.06-0.13$ & $18.3-36.6$ & $10.9-17.3$ & $13.6-16.3$ & Lestari, 2011 \\
\hline Brest Harbour, France & - & 700 & 500 & 1160 & Cabon, et. al., 2010 \\
\hline Masan Bay, Korea & 1.24 & 43.40 & 43.97 & - & Hyun, et. al., 2007 \\
\hline Mexican Caribbean & - & 1.3 & 1 & - & Whelan III, et. al., 2011 \\
\hline $\begin{array}{l}\text { Andaman Islands, India } \\
\text { (sandy ecosystem) }\end{array}$ & $0.69-1.96$ & $6.64-7.04$ & - & $10.4-27.72$ & Nobi, et. al., 2010 \\
\hline $\begin{array}{l}\text { Andaman Islands, India } \\
\text { (dead coral ecosystem) }\end{array}$ & $1.24-1.75$ & $5.48-10.58$ & - & $25.54-38.77$ & Nobi, et. al., 2010 \\
\hline $\begin{array}{l}\text { Andaman Islands, India } \\
\text { (seagrass ecosystem) }\end{array}$ & $1.04-3.88$ & $44.36-86.76$ & $3.08-6.64$ & $21.64-48.72$ & Nobi, et. al., 2010 \\
\hline $\begin{array}{l}\text { Andaman Islands, India } \\
\text { (mangrove ecosystem) }\end{array}$ & $0.8-1.52$ & $80.86-87.93$ & $3.9-5.4$ & $12.21-23.02$ & Nobi, et. al., 2010 \\
\hline Abundance in the continent crust & 0.2 & 55 & 12.5 & 70 & Taylor, 1964 \\
\hline Lampung bay, Indonesia & $0.01-0.08$ & $5.30-22.99$ & $6.05-24.73$ & $33.14-118.48$ & This study \\
\hline
\end{tabular}

Table 5.

Grain Size classification of the sediment in each station of The Lampung Bay

\begin{tabular}{|c|c|c|c|c|c|c|}
\hline \multirow[t]{2}{*}{ Station } & \multirow[b]{2}{*}{ Pebbles } & \multicolumn{4}{|c|}{ Sediment Classification (\%) } & \multirow[t]{2}{*}{ Remark } \\
\hline & & Granules & Sand & Silt & Clay & \\
\hline st 1 & 0 & 0 & 4,32 & 52,64 & 43,04 & Urban area \\
\hline st 2 & 0 & 1,83 & 5,74 & 27,5 & 64,93 & Urban area \\
\hline st 3 & 0 & 0 & 14,22 & 42,2 & 43,57 & River Mouth \\
\hline st 4 & 0 & 4 & 35,45 & 22,04 & 38,51 & - \\
\hline st 5 & 0 & 0 & 1,66 & 48,87 & 50,46 & Aquaculture area \\
\hline st 6 & 0 & 0 & 6,02 & 53,41 & 40,57 & Aquaculture area \\
\hline st 7 & 9,14 & 8,52 & 11,78 & 28,55 & 42,02 & Aquaculture area \\
\hline st 8 & 13,73 & 11,67 & 12,96 & 23,48 & 38,16 & Industrial area \\
\hline st 9 & 0 & 0,38 & 13,55 & 56,6 & 29,47 & Aquaculture area \\
\hline st 10 & 0 & 7,16 & 18,68 & 33,78 & 40,39 & Aquaculture area \\
\hline st 11 & 0 & 0,73 & 3,55 & 32,34 & 63,37 & Industrial area \\
\hline st 12 & 0 & 0,74 & 4,36 & 54,63 & 40,27 & Industrial area \\
\hline st 13 & 0 & 0 & 3,92 & 47,05 & 49,03 & - \\
\hline
\end{tabular}




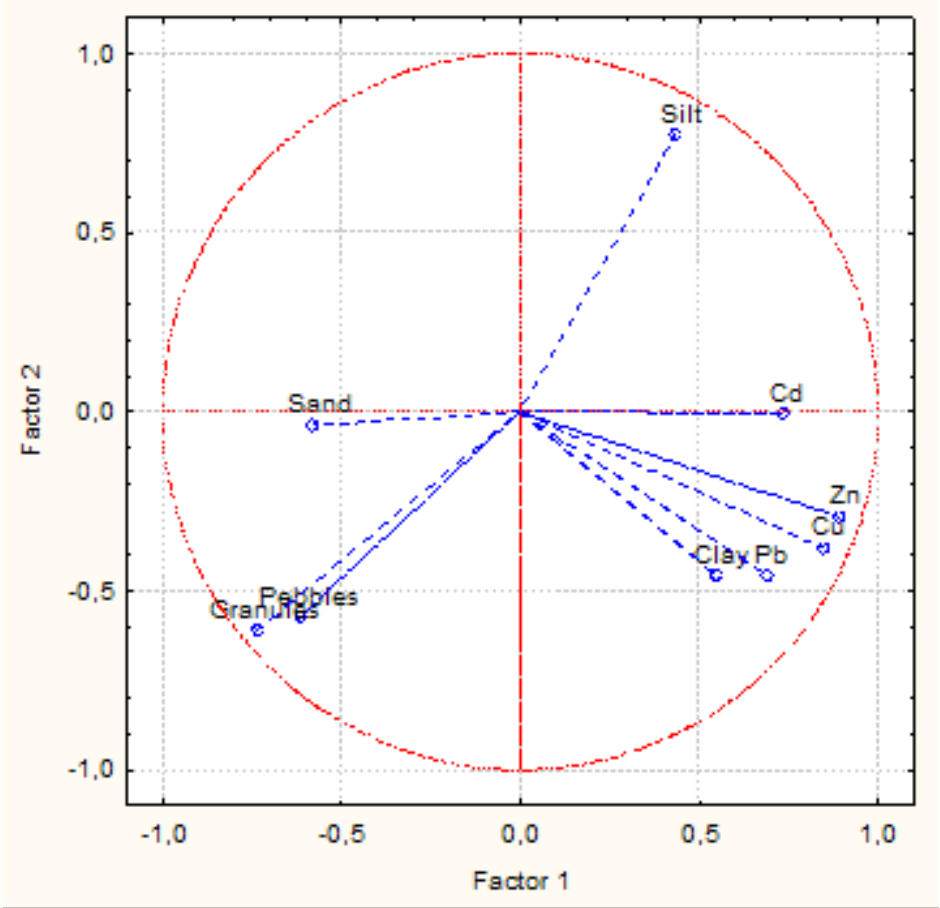

Figure 2. Principal Components Analysis for sediment fraction and concentration of metals in sediment.

Table 6 .

SQG-Q index for each station

\begin{tabular}{|c|c|c|c|c|c|}
\hline \multirow{2}{*}{ Station } & \multicolumn{4}{|c|}{ PEL-Qi } & \multirow{2}{*}{ SQG-Q } \\
\hline & $\mathrm{Pb}$ & $\mathrm{Cd}$ & $\mathrm{Cu}$ & $\mathrm{Zn}$ & \\
\hline st.1 & 0,193 & 0,0114 & 0,191 & 0,410 & 0,20 \\
\hline st. 2 & 0,221 & 0,0124 & 0,213 & 0,437 & 0,22 \\
\hline st. 3 & 0,054 & 0,0188 & 0,169 & 0,366 & 0,15 \\
\hline st. 4 & 0,065 & 0,0074 & 0,049 & 0,130 & 0,06 \\
\hline st.5 & 0,109 & 0,0100 & 0,156 & 0,264 & 0,13 \\
\hline st. 6 & 0,107 & 0,0100 & 0,119 & 0,228 & 0,12 \\
\hline st.7 & 0,089 & 0,0026 & 0,102 & 0,235 & 0,11 \\
\hline st. 8 & 0,082 & 0,0038 & 0,078 & 0,122 & 0,07 \\
\hline st.9 & 0,082 & 0,0062 & 0,082 & 0,212 & 0,10 \\
\hline st. 10 & 0,083 & 0,0076 & 0,084 & 0,233 & 0,10 \\
\hline st.11 & 0,085 & 0,0088 & 0,077 & 0,216 & 0,10 \\
\hline st.12 & 0,088 & 0,0050 & 0,066 & 0,196 & 0,09 \\
\hline st.13 & 0,089 & 0,0050 & 0,077 & 0,199 & 0,09 \\
\hline
\end{tabular}

of Lampung Bay showed no extreme differences with the average abundance within continental crust in preindustrial period. Metal concentration in sediment in the Lampung Bay was lower than other areas like harbor and other urban waters (Table 4). This study supported the report in metal's bioaccumulation in Lampung Bay (Tugiyono, 2007) that discovered that $\mathrm{Hg}$ and $\mathrm{Pb}$ concentration in Lampung Bay was not dangerous for marine organisms. The concentration of $\mathrm{Hg}$ and $\mathrm{Pb}$ in green mussle (Perna viridis) increased, yet those concentrations surpassed none of existing regulation.

\section{SQG-Q index}

SQG-Q index value varied among station as the metals concentration differed among locations. $\mathrm{Zn}$ contributed the most in the calculation of SQG-Q index than other metals due to the high concentration of $\mathrm{Zn}$ compared with PEL value. Interpreting the SQG-Q index, 7 stations (more than a half of total stations) were unimpacted area and moderate impact was found in the rest of the stations (Table 6). The presence of metals in sediment will expose metals accumulation in benthic organism in various mechanisms. The effect of metals accumulation in organism differs in each metal, depending on: intake rate, exposure route, internal 
factor of organisms (ages, sex) and physiochemical properties of environment (Luoma \& Rainbow, 2008). $\mathrm{Cd}$ and $\mathrm{Pb}$ categorized as non-essential element having toxic effect even in low concentration. In contrast, $\mathrm{Cu}$ and $\mathrm{Zn}$ were essential elements used in metabolisms, however, exceeding concentration has toxic potential. In recent research, $\mathrm{Cd}$ was found to substitute $\mathrm{Zn}$ and its function in carbonic anhydrase enzyme of diatomae when the seawater lacked $\mathrm{Zn}$. In this state, diatomae could maintain its growth rate, however, this phenomenon still is not be observed in higher trophic level organisms (Lane et. al., 2005).

SQG-Q index calculates the sum of measured concentration and quality guideline (in this study, PEL was used), and it predicts toxicity of metals in sediment. The achieved score predicted the influence of metal's abundance in benthic organism, however, real adverse effect of metals to organism could not be determined by these scores only. The effect of metals bioaccumulation to marine organism is complex (Luoma \& Raibow, 2008). The changes of water properties may affect the toxicity of sediment. The presence of other chemical components like sulphide or organic material influence metals bioavailabity. In metal-sulphide compound, metals were strongly bound and in this state metals mobility considered low, resulted in low toxicity effect of sediment to marine organism. Furthermore, the existence of other metals caused different impact on toxicity, particularly interaction of metal with one another. In most cases, the poisoning effect of $\mathrm{Cd}$ can be prevented by $\mathrm{Zn}$ consumption and the consumption of $\mathrm{Cd}$ decreases Cu concentration in the liver (Darmono, 1995).

\section{CONCLUSION}

Anthropogenic activities along Lampung Bay coastal area altered $\mathrm{Cd}, \mathrm{Cu}, \mathrm{Pb}$ and $\mathrm{Zn}$ concentration in bottom sediment. $\mathrm{Cu}, \mathrm{Pb}$ and $\mathrm{Zn}$ concentrated in urban and aquaculture area which represent human activity. However, $\mathrm{Cd}$ distributed evenly in the Bay due to low concentration of $\mathrm{Cd}$ in the natural sediment indicating another factor, such as sediment fraction also contributed in its concentration. Urban and aquaculture area are covered by finer sediment than other areas in the Lampung Bay resulted in high metals concentration. Comparison with previous study areas, $\mathrm{Cd}, \mathrm{Cu}, \mathrm{Pb}$ and $\mathrm{Zn}$ in the Lampung Bay were relatively low. Calculation of SQG-Q index showed that more than half of the total observation stations were claimed to unimpacted area and the others were in moderate impact state.

\section{ACKOWLEDGEMENTS}

This study was funded by DIPA Research Centre for Oseanography-LIPI. We acknowledge Prof. Pramudji as researcher in chief and our deep thanks to
Mr. Abdul Rozak and Mr. M. Taufik Kaisupy for assisting laboratory analysis.

\section{REFFERENCES}

Cabon, J.Y., P. Giamarchi \& S.L. Floch. (2010). A study of marine pollution caused by the release of metals into seawater following acid spills. Marine Pollution Bulletin 60: 998-1004.

Caeiro, S., M.H. Costa, T.B. Ramos, F. Fernandes, N. Silveira, A. Coimbra, G. Medeiros \& M. Painho, (2005). Assessing heavy metal contamination in Sado Estuary sediment: An index analysis approach. Ecological Indicators 5: 151-169.

Cappenberg, H.A.W., (2010). Komposisi jenis dan distribusi moluska di perairan Teluk Lampung. In: Ruyitno dkk. (Ed.). Status Sumber daya laut di perairan Teluk Lampung: 14-24. Jakarta: LIPI Press.

Ciutat, A., M. Gerino, \& A. Boudou, (2007). Remobilization and bioavailability of cadmium from historical contaminated sediments: Influence of biotubation by tubificids. Ecotoxicology and Environmental Safety 68: 108-117.

Darmono. (1995). Logam dalam sistem biologi makhluk hidup. Jakarta: UI Press. 136 hlm.

Dean, R.J., T.M. Shimmield \& K.D. Black, (2007). Copper, zinc and cadmium in marine cage fish farm sediments: An extensive survey. Environmental Pollution 145: 84-95.

Donazzolo, R., O. Hieke-Merlin, L. Menagazzo-Vitturi \& B. Pavoni, (1984). Heavy metal content and lithological properties of recent sediments in the Northern Adriatic. Marine Pollution Bulletin 15: 93-101.

Ellwood, M.J., (2004). Zinc \& cadmium speciation in subantarctic waters east of New Zealand. Marine Chemistry 87: 37-58.

Fitriya, N., (2010). Kelimpahan zooplankton di perairan Teluk Lampung. In: Ruyitno dkk. (Ed.). Status Sumber daya laut di perairan Teluk Lampung: 104-112. Jakarta: LIPI Press.

Handayani, T., (2010). Makroalgae ekonomis penting di perairan Teluk Lampung. In: Ruyitno dkk. (Ed.). Status Sumber daya laut di perairan Teluk Lampung: 25-31. Jakarta: LIPI Press.

Helfinalis, (2010). Lingkungan pantai, endapan sedimen dan total suspended solid di Perairan 
Teluk Lampung. In: Ruyitno dkk. (Ed.). Status Sumber daya laut di perairan Teluk Lampung: 205-219. Jakarta: LIPI Press.

Hosono, T., C.C. Su, F. Siringan, A. Amano \& S.I. Onodera, (2010). Effect of environmental regulations on heavy metal pollution decline marine core sediments from Manila Bay. Marine Pollution Bulletin 60: 780-785.

Hutagalung, H.P., Setiapermana, D. \& Riyono, S.H., (1997). Metode analisis air laut, sedimen dan biota, Buku 2. Jakarta: P3O LIPI. 182 hlm.

Hyun, S., C.H. Lee, T. Lee \& J.W. Choi, (2007). Anthropogenic contributions to heavy metal distributions in the surface sediments of Masan Bay, Korea. Marine Pollution Bulletin 54: 10311071.

Kadi, A., (2010). Karakteristik komunitas rumput laut beserta interaksi antar jenis di perairan Teluk Lampung. In: Ruyitno dkk. (Ed.). Status Sumber daya laut di perairan Teluk Lampung: 51-62. Jakarta: LIPI Press.

Lane, T.W., M.A. Saito, G.N. George, I.J. Pickering, R.C. Prince, \& F.M.M. Morel, (2005). A cadmium enzyme from a marine diatom. Nature Publishing Group 435: 42.

Lee, J.G. \& F.M.M. Morel. (1985). Replacement of zinc by cadmium in marine phytoplankton. Marine Ecology Progress Series. 127: 305-309.

Lestari, (2011). Distribusi dan geokimia logam berat dalam sedimen di Perairan Semarang, Jawa Tengah. In: A. Hartoko dkk. (Ed.). Prosiding Pertemuan IImiah Nasional Tahunan VIII ISOI 2011: 204-217. Makassar: Ikatan Sarjana Oseanologi Indonesia.

Lestari \& Y. Witasari. (2010). Kualitas perairan di Teluk Lampung ditinjau dari aspek logam berat, In: Ruyitno dkk. (Ed.). Status Sumber daya laut di perairan Teluk Lampung: 160-170. Jakarta: LIPI Press.

Local Government of Lampung, (1999). Atlas sumberdaya wilayah pesisir lampung. Bandar Lampung: Pemerintah Daerah Provinsi Lampung. $80 \mathrm{hlm}$.

Luoma, S.N. \& P.S. Rainbow, (2008). Metal contamination in aquatic environments: Science and lateral Management. United Kingdon: Cambridge University press. $556 \mathrm{hlm}$.
Martincic, D., Z. Kwokal \& M. Branica, (1990). Distribution of zinc, cadmium and copper between different size fractions of sediments I. The Limski Kanal (North Adriatic Sea). The Science of the Total Environment 95: 201-215.

Nobi, E.P., E. Dilipan, T. Thangaradjou, K. Sivakumar \& L. Kannan, (2010). Geochemical and geo-statistical assessment of heavy metal concentration in the sediments of different coastal ecosystems of Adaman Islands, India. Estuarine, Coastal and Shelf Science 87: 253-264.

Olsgard, F., (1999). Effect of copper contamination on recolonisation of subtidal marine soft sedimentan experimental field study. Marine Pollution Bulletin 38: 448-462.

Pramudji, (2010). Mangrove di kawasan pesisir Teluk Lampung, Provinsi Lampung. In: Ruyitno dkk. (Ed.). Status Sumber daya laut di perairan Teluk Lampung: 1-13. Jakarta: LIPI Press.

Rejomon, G., M. Nair \& T. Joseph, (2010). Trace metal dynamics infishes from the Southwest coast of India. Environment Monitoring Assessment. 167: 243-255.

Rochyatun, E., Edward \& A. Rozak, (2003). Kandungan logam berat $\mathrm{Pb}, \mathrm{Cd}, \mathrm{Cu}, \mathrm{Zn}, \mathrm{Ni}, \mathrm{Cr}, \mathrm{Mn} \&$ Fe dalam air laut dan sedimen di perairan Kalimantan Timur. Oseanologi dan Limnologi di Indonesia 35: 51-71.

Rochyatun, E., (2003). Kadar logam berat dalam air laut dan sedimen di Perairan Gugus Pulau Pari. In: Ruyitno dkk. (Ed.). Pesisir dan Pantai Indonesia VIII: 99-104. Jakarta: P2O-LIPI.

Rochyatun, E., Lestari \& A. Rozak, (2004). Kondisi perairan Muara Sungai Digul dan Perairan Laut Arafura dilihat dari kandungan logam berat. Oseanologi dan Limnologi di Indonesia. 36: 1531.

Rochyatun, E., Lestari \& A. Rozak, (2005). Kualitas lingkungan perairan Banten dan sekitarnya ditinjau dari kondisi logam berat. Oseanologi dan Limnologi di Indonesia. 38: 23-46.

Rochyatun, E., M.T. Kaisupy \& A. Rozak. (2006) Distribusi logam berta dalam air dan sedimen di perairan muara Sungai Cisadane. Makara Sains. 10 (1): 35-40.

Rompas, R.M., (2010). Toksikologi kelautan. Jakarta: Sekretariat Dewan Kelautan Indonesia. $75 \mathrm{hlm}$.

Sanusi, H.S., (2006). Kimia Laut: Proses fisik kimia 
dan interaksinya dengan lingkungan. Bogor: Departemen IImu dan Teknologi Kelautan, Fakultas Perikanan dan IImu Kelautan, Institut Pertanian Bogor. 188 hlm.

Susana, T, Suyarso \& M. Muchtar, (2001). Karakteristik beberapa parameter kimia, kaitannya dengan tataguna lahan perairan Teluk Lampung. In: Aziz, $A$ and M. Muchtar (Ed.). Perairan Indonesia: Oseanografi, Biologi dan Lingkungan: 43-53. Jakarta: P3O LIPI.

Taylor, S.R., (1964). Abundance of chemical elements in the continental crust: a new table. Geochimica et Cosmochimica Acta.28: 1273-1285.

Thoha, H., (2010). Fitoplankton di perairan Teluk Lampung. In: Ruyitno dkk. (Ed.). Status Sumber daya laut di perairan Teluk Lampung: 96-103. Jakarta: LIPI Press.

Tugiyono. (2007). Bioakumulasi logam $\mathrm{Hg}$ dan $\mathrm{Pb}$ di perairan Teluk Lampung, Propinsi Lampung. Jurnal Sains MIPA. 13 (1): 44-48.

United State of Environmental Protection Agency, (1996). Test methods for evaluating solid waste. SW-846 Methods 3050B.

Whelan III, T., B.I. Van Tussenbroek \& M.G.B. Santos, (2011). Changes in trace metals in Thalassia testudirum after hurricane impact. Marine Pollution Bulletin 62: 2797-2802. 